\title{
Regulation of atrial natriuretic peptide (ANP) and its role in blood pressure
}

\author{
Feroz Ahmed, *Nahida Tabassum, Saima Rasool \\ Department of Pharmaceutical Sciences, Pharmacology Division, University of Kashmir, Srinagar-190 006, India
}

\begin{abstract}
Atrial natriuretic peptide (ANP) a powerful vasodilator, and a protein (28-amino acid peptide) hormone secreted by heart muscle cells. It is released in response to atrial distention, stretching of the vessel walls, sympathetic stimulation of $\beta$-adrenoceptors, raised sodium concentration, angiotensin-II and endothelin. ANP binds to three cell surface receptors called ANP receptors. The overall effect of ANP on the body is to counter increases in blood pressure and volume caused by the renin-angiotensin system. It has also been reported to increase the release of free fatty acids from adipose tissue. Regulation of its effects is achieved through gradual degradation of the peptide by the enzyme neutral endopeptidase (NEP). Inhibitors of NEP are currently being developed to treat disorders ranging from hypertension to heart failure. Synthetic analogs of ANP have been investigated as potential therapies for the treatment of decompensated heart failure and other diseases.
\end{abstract}

Key Words: Atrial natriuretic peptide, ANP receptors, Hypertension, Angiotensin.

\section{INTRODUCTION}

Atrial natriuretic peptide (ANP), atrial natriuretic factor (ANF), atrial natriuretic hormone $(\mathrm{ANH})$, or atriopeptin, is a powerful vasodilator, and a protein (polypeptide) hormone secreted by heart muscle cells. It is involved in the homeostatic control of body water, sodium, potassium and fat (adipose tissue) (Widmaier et al., 2008). ANP is the most abundant of a family of at least three structurally and functionally related peptide hormones that exert widespread effects on cardiovascular and renal function. Under normal hemodynamic conditions, it is predominantly synthesized, stored, and secreted in a regulated fashion by modified myocytes of the cardiac atria. However, in pathophysiological conditions of hemodynamic overload (in congestive heart failure, ventricular synthesis of the peptide) it is reactivated and contributes significantly to the circulating pool of the peptide. In lesser amounts, it is synthesized in some peripheral tissues, in the vasculature, and in central nervous structures (Potter et al., 2009).

\footnotetext{
*Corresponding Author:

Dr. Nahida Tabassum

Associate professor, Pharmacology Division

Department of Pharmaceutical Sciences

University of Kashmir, Srinagar, J \& K, India-190006

E-mail: n.tabassum.uk@gmail.com

Contact No.: +91-9419407326
}

ANP is a 28 -amino acid peptide with a 17 -amino acid ring in the middle of the molecule. The ring is formed by a disulfide bond between two cysteine residues at positions 7 and 23. ANP is closely related to BNP (brain natriuretic peptide) and CNP (C-type natriuretic peptide) and all have the same amino acid ring (De Bold, 1985).

\section{REGULATION OF ANP}

ANP is produced, stored and released by cardiac myocytes of the atria of the heart. It is released in response to atrial stretch and a variety of other signals induced by hypervolemia, exercise or caloric restriction (Widmaier et al., 2008). The hormone is constitutively expressed in the ventricle in response to stress induced by increased afterload (e.g. increased ventricular pressure from aortic stenosis) or injury (e.g. myocardial infarction). The secretion of ANP is regulated by following factors:

\section{Atrial distension \\ Plasma concentration of ANP increases in response to volume expansion in anesthetized rats (Lang et al., 1985). Experiments in chloralose-anesthetized dogs have demonstrated that mitral valve obstruc- tion, increases plasma ANP levels which is not}


Table 1: Types of ANP receptors (Widmaier et al., 2008).

\begin{tabular}{|c|c|c|}
\hline No. & Type & Name \\
\hline \multirow[t]{2}{*}{1} & GC-A & Guanylyl cyclase-A \\
\hline & NPRA/ANPA or NPR1 & $\begin{array}{l}\text { Natriuretic peptide } \\
\text { receptor-A }\end{array}$ \\
\hline \multirow[t]{2}{*}{2} & GC-B & Guanylyl cyclase-B \\
\hline & NPRB/ANPB or NPR2 & $\begin{array}{l}\text { Natriuretic peptide } \\
\text { receptor-B }\end{array}$ \\
\hline 3 & NPRC/ANPC or NPR3 & $\begin{array}{l}\text { Natriuretic peptide } \\
\text { clearance receptor-B }\end{array}$ \\
\hline
\end{tabular}

attenuated by vagotomy (Ledsome, 1985). ANP has been found to increase in humans with water immersion (Epstein et al., 1989), in clinical conditions such as heart failure (Tikkanen et al., 1985) and renal failure (Rascher et al., 1985). Rate of contraction has been suggested to stimulate ANP secretion (Schiebinger and Linden, 1986). ANP secretion is substantially augmented in experimental animals with cardiac hypertrophy or heart failure where gene expression of the hormone is increased in both the atria and ventricles (Ruskoaho, 1992).

\section{Cardiac ischemia}

Ischemia is one of the most potent stimuli for ANP secretion, which can be viewed as an important homeostatic mechanism since ANP can produce cardiac vasodilatation to increase blood flow and oxygen delivery to the heart as well as peripheral vasodilatation to reduce arterial pressure. The reduction in cardiac after load results in a beneficial reduction in cardiac oxygen demand. Nocturia, seen with obstructive sleep apnea, has recently been attributed to increased secretion of ANP. Plasma ANP levels in sleep apnea correlate directly with the degree of hypoxemia but also could be stimulated by hemodynamic mechanisms such as pulmonary hypertension, which elevates right heart pressures. Also, myocardial infarction leads to acute cardiac ischemia and a profound increase in the release of ANP in both animals (Tikkanen et al., 1987) and humans (Tan et al., 1989).

\section{Endothelin}

Endothelin-1 is one of the most potent stimuli for ANP secretion (Lew and Baertschi, 1989). Endothelin increases ANP secretion and up-regulates ANP messenger RNA in isolated rat cardiac myocytes. It has been proved that a specific endothelin-1 receptor antagonist attenuates the ANP response to atrial stretch (Skvorak et al., 1995), thus demonstrating that endothelin plays an essential paracrine role in the stretch-activated ANP secretory process. High atrial pressure $(8-10 \mathrm{mmHg}$ ) produces a marked increase in ANP secretion (30-60 min) compared to the low atrial pressure control period. Endothelin further augments this response when added while atrial pressure is elevated (60-90 min) (Pollack et al., 1997).

\section{Nitric oxide (NO)}

$\mathrm{NO}$ is a potent vasodilator which is produced from L-arginine and increases the production of c GMP in both cardiac muscle and vascular smooth muscle (Moncada et al., 1991). An infusion of the NO synthase inhibitor, NG-nitro-L-arginine methyl ester (L-NAME), when given to conscious rats augments ANP secretion in response to blood volume expansion (Leskinen et al., 1985). ANP secretion is increased by $150 \%$ by increasing atrial pressure from 2 to $10 \mathrm{mmHg}$ (Skvorak et al., 1996).

Angiotensin II, Vasopressin and Adrenergic agonists Angiotensin, vasopressin and phenylephrine when infused in anesthetized rats produce changes in the plasma concentration of ANP correlated directly with changes in atrial pressure (Katsube et al., 1985). An increase in plasma ANP in rats occurs with angiotensin infusion at doses that did not alter atrial or left ventricular end-diastolic pressures (Lachance et al., 1988). In vitro studies have produced contradictory results. Several vasoconstrictor hormones including norepinephrine, epinephrine, angiotensin II and vasopressin can increase ANP secretion by indirect mechanisms related to vasoconstriction and increased atrial and ventricular stretch.

\section{Neurohumoral factors}

Calcium: It plays a central role in secretion mechanisms of many hormones. ANP secretion is found to be independent of changes in extracellular calcium even in the presence of EGTA, a calcium chelator (De Bold, 1989). BAY K 8644, a calcium channel agonist that increases calcium entry into cardiac myocytes and increases cardiac contractility, is found to stimulate ANP secretion in atrial myocyte cultures (Irons et al., 1992). It is also postulated that calcium has a negative effect on ANP secretion under basal conditions but a positive modulatory 
role under conditions of stimulated sustained release (Doubell et al., 1994).

Nucleotides: For ANP secretion both cAMP and cGMP appear to be inhibitory. Forskolin, which increases cellular cAMP, inhibits ANP secretion in atrial myocytes (Iida and Page, 1988; Muir et al., 1993). A number of humeral factors appear to inhibit ANP secretion by stimulating cAMP including adrenomedullin, $\alpha$-adrenergic agents such as isoproterenol, (Muir et al., 1993) histamine, (Li et al., 2003) and phosphodiesterase-3 inhibitors (Cui et al., 2002). Also, cGMP inhibits ANP and appears to mediate the actions of nitric oxide and C-type natriuretic peptide on ANP secretion (Lee et al., 2000).

Prostaglandins: It has been demonstrated that prostaglandins play a critical role in the stimulus secretion mechanism for ANP secretion. $\mathrm{PGF}_{2} \alpha$ and $\mathrm{PGE}_{2}$ but not $\mathrm{PGI}_{2}$ stimulate ANP synthesis and secretion in rats in vivo and in cultured rat atrial myocytes (Gardner and Schultz, 1990). Others have reported that prostaglandins are a potent stimulator of ANP secretion in rat ventricular myocytes and rabbit atria sections (Gardner et al., 1992).

Kinases: Several protein kinases have been implicated in the stimulus-secretion coupling for ANP secretion. Phorbol esters, which increase the cellular concentration of protein kinase C (PKC), stimulate ANP secretion from the isolated rat heart (Ruskoaho et al., 1986). Staurosporine, a protein kinase inhibitor, blocks Forskolin-induced inhibition of ANP secretion in the perfused rabbit atria (Cui et al., 2002). It has been found that the tyrosine kinase inhibitor, lavendustin, blocks stretch-induced ANP release (Taskinen et al., 1999). However, a study has also shown that another tyrosine kinase inhibitor, genistein, stimulates ANP release.

\section{CONCLUSION}

ANP plays a determining role in long-term regulation of arterial pressure. At normal salt intake, ANP by itself is not the determining factor in renal regulation of salt excretion but only one of several redundant natriuretic mechanisms, whose activity may not be absolutely essential in isolation. However, ANP-mediated antagonism of RAS is essential for the cardiovascular and renal adaptations to chronically elevated dietary salt intake. The overall effect of ANP on the body is to counter increases in blood pressure and volume caused by the reninangiotensin system.

\section{REFERENCES}

Cui X, Wen JF, Jin H, Li D, Jin JY, Kim SH, et al. (2002). Subtype-specific roles of cAMP phosphodiesterases in regulation of atrial natriuretic peptide release. European Journal of Pharmacology, 451, 295-302. [DOI]

De Bold AJ. (1985). Atrial natriuretic factor: a hormone produced by the heart. Science Mag, 230, 767-70.

De Bold ML, De Bold AJ. (1989). Effect of manipulations of $\mathrm{Ca}^{2+}$ environment on atrial natriuretic factor release. Am J Physiology, 256, H1588-94. PMid:2525346

Doubell AF, Thibault G. (1994). Calcium is involved in both positive and negative modulation of the secretory system for ANP. Am J Physiology, 266, H1854-63. PMid:8203584

Epstein M, Norsk P, Loutzenhiser R. (1989). Effects of water immersion on atrial natriuretic peptide release in humans. Am J Nephrology, 9, 1-24. [DOI] PMid:2524162

Gardner DG and Schultz HD. (1990). Prostaglandins regulate the synthesis and secretion of the atrial natriuretic peptide. J Clin Investigation, 86, 52-9. [DOI] PMid:2142168 PMCid:296689

Gardner DG, Wirtz H, Dobbs LG. (1992). Stretch-dependent regulation of atrial peptide synthesis and secretion in cultured atrial cardiocytes. Am J Physiology, 263, E239-44. PMid:1381150

Iida H, Page E. (1988). Inhibition of atrial natriuretic peptide secretion by forskolin in noncontracting cultured atrial myocytes. Biochem Biophys Res Communcation, 157, 3306. [DOI]

Irons CE, Sei CA, Hidaka H, Glembotski CC. (1992). Protein kinase $\mathrm{C}$ and calmodulin kinase are required for endothelin-stimulated atrial natriuretic factor secretion from primary atrial myocytes. J Biol Chemistry, 267, 5211-6. PMid:1371996

Katsube N, Schwartz D, Needleman P. (1985). Release of atriopeptin in the rat by vasoconstrictors or water immersion correlates with changes in right atrial pressure. Biochem Biophys Res Communcation, 133, 937-44. [DOI]

Lachance D, Garcia R. (1988). Atrial natriuretic factor release by angiotensin II in the conscious rat. Hypertension, 11, 502-8. PMid:2968308

Lang RE, Thölken H, Ganten D, Luft FC, Ruskoaho H, Unger T. (1985). Atrial natriuretic factor--a circulating hormone stimulated by volume loading. Nature, 314, 264-6. [DOI] PMid:3157062 
Ledsome JR, Wilson N, Courneya CA, Rankin AJ. (1985). Release of atrial natriuretic peptide by atrial distension. Can J Physiol Pharmacology, 63, 739-742. [DOI] PMid:2931169

Lee SJ, Kim SZ, Cui X, Kim SH, Lee KS, Chung YJ, et al. (2000). C-type natriuretic peptide inhibits ANP secretion and atrial dynamics in perfused atria: NPR-B-cGMP signaling. Am J Physiol Heart Circ Physiology, 278, H208H221. PMid:10644601

Leskinen H, Vuolteenaho O, Leppäluoto J, Ruskoaho H. (1985). Role of nitric oxide on cardiac hormone secretion: effect of NG-nitro-L-arginine methyl ester on atrial natriuretic peptide and brain natriuretic peptide release. Endocrinology, 136, 1241-9. [DOI] PMid:7867578

Lew RA, Baertschi AJ. (1989). Endothelial cells stimulate ANF secretion from atrial myocytes in co-culture. Biochem Biophys Res Communcation, 163, 701-709. [DOI]

Lew RA, Baertschi AJ. (1989). Mechanisms of hypoxiainduced atrial natriuretic factor release from rat hearts. Am J Physiology, 257, H147-56. PMid:2526588

Li D, Wen JF, Jin JY, Jin H, Ann HS, Kim SZ, Kim SH, Lee HS, Cho KW. (2003). Histamine inhibits atrial myocytic ANP release via $\mathrm{H} 2$ receptor-cAMP-protein kinase signaling. Am J Physiol Regul Integr Comp Physiology, 285, R380R393. PMid:12714356

Moncada S, Palmer RM, Higgs EA. (1991). Nitric oxide: physiology, pathophysiology, and pharmacology. Pharmacol Reviews, 43, 109-142. PMid:1852778

Muir TM, Hair J, Inglis GC, Dow JW, Lindop GB, Leckie BJ. (1993). Hormonal control of atrial natriuretic peptide synthesis and secretion from cultured atrial myocytes. J Mol Cell Cardiology, 25, 509-518. [DOI] PMid:8377212

Pollack JA, Skvorak JP, Nazian SJ, Landon CS, Dietz JR. (1997). Alterations in atrial natriuretic peptide (ANP) secretion and renal effects in aging. J Gerontol A Biol Sci Med Science, 52, B196-202. [DOI]

Potter LR, Yoder AR, Flora DR, Antos LK, Dickey DM. (2009). Natriuretic peptides: their structures, receptors, physiologic functions and therapeutic applications. Handb Exp Pharmacology, 341-366.

Rascher W, Tulassay T, Lang RE. (1985). Atrial natriuretic peptide in plasma of volume-overloaded children with chronic renal failure. Lancet, 2, 303-305. [DOI]
Ruskoaho H, Toth M, Ganten D, Unger T, Lang RE. (1986). The phorbol ester induced atrial natriuretic peptide secretion is stimulated by forskolin and Bay K8644 and inhibited by 8-bromo-cyclic GMP. Biochem Biophys Res Communcation, 139, 266-274. [DOI]

Ruskoaho H. (1992). Atrial natriuretic peptide: synthesis, release and metabolism. Pharmacol Reviews, 44(4): 479602. PMid:1480667

Schiebinger RJ, Linden J. (1986). Effect of atrial contraction frequency on atrial natriuretic peptide secretion. Am J Physiology, 251, H1095- H1099. PMid:2946242

Skvorak JP, Dietz JR. (1997). Endothelin and nitric oxide interact to regulate stretch-induced ANP secretion. Am J Physiology, 273, R301- R306. PMid:9249564

Skvorak JP, Nazian SJ, Dietz JR. (1995). Endothelin acts as a paracrine regulator of stretch-induced atrial natriuretic peptide release. Am J Physiology, 269, R1093-R1098. PMid:7503296

Skvorak JP, Sutton ET, Rao PS, Dietz JR. (1996). Mechanism of anoxia-induced atrial natriuretic peptide release in the isolated rat atria. Am J Physiology, 271, R237-R243. PMid:8760226

Tan AC, van Loenhout TT, Lamfers EJ, Hooghoudt TE, Kloppenborg PW, Benraad TJ. (1989). Atrial natriuretic peptide after myocardial infarction. Am Heart Journal, 118, 490-494. [DOI]

Taskinen P, Toth M, Vuolteenaho O, Magga J, Ruskoaho H. (1999). Inhibition of atrial wall stretch-induced cardiac hormone secretion by lavendustin $\mathrm{A}$, a potent tyrosine kinase inhibitor. Endocrinology, 140, 4198-4207. [DOI] PMid:10465292

Tikkanen I, Fyhrquist F, Metsärinne K, Leidenius R. (1985) Plasma atrial natriuretic peptide in cardiac disease and during infusion in healthy volunteers. Lancet, 2, 66-69. [DOI]

Tikkanen T, Tikkanen I, Fyhrquist F. (1987) Elevated plasma atrial natriuretic peptide in rats with myocardial infarcts. Life Sciences, 40, 659-663. [DOI]

Widmaier, Eric P. Hershel Raff, Kevin T. Strang. (2008) Vander's Human Physiology, 11th Ed. McGraw-Hill, 291, 509-510. 